\title{
INTERVIEW
}

\section{Interview with Colette Paul by Mick Gowar}

Q: You are a writer of short stories, a form which publishers have often been wary of in the past. Do you think that's still the case?

A: Publishers seem to have a fear of short stories, and I think it's got worse as the industry has become more commercially driven - so lots of publishers now say, 'No short stories', and they won't even look at them or consider them. It's a different situation in America where people still have plenty of opportunities to publish short stories, and short stories win big prizes, like Jhumpa Lahiri's Interpreter of Maladies (Lahiri 1999) ${ }^{1}$ which won the Pulitzer Prize and the Hemingway prize. But I think British publishers run scared of short stories. There seems to be a fundamental marketing problem with short stories - for example, when I pick up a novel and the blurb says it's about horse racing, I'll put it down because I'm not interested in horse racing. But a book of short stories is much more difficult to categorize in terms of subject matter, and I think that puts potential readers off - it's a mixed bag, and they don't know what they're going to get.

Q: But aren't there more outlets for short stories now on the radio and newer media - blogs, and story websites? How many times were the stories from Whoever You Choose To Love (Paul 2005) broadcast, for example?

A: The stories were recorded once, but then repeated a lot. Apart from broadcasting, the Internet, of course, is a perfect forum for short stories, and there are lots of campaign sites like Save Our Short Story ${ }^{2}$ and Short Story Week. ${ }^{3}$ As far as broadcasting, at the moment there's Radio 4, Radio 4 Extra, Radio Scotland and a lot of regional radio stations broadcasting short stories. There's
1. Interpreter of Maladies, was winner of the Pulitzer Prize for Fiction, 2000, the Hemingway Foundation/Pen Award 2000, and also The New Yorker's 'Best Debut of the Year' and on Oprah Winfrey's 'Top Ten Book List'. She has since published a second collection of short stories, Unaccustomed Earth (2008) and a nove The Namesake (2003). Lahiri is a member of The President's Committee on the Arts and the Humanities.

2. http://www. theshortstory.org.uk/ aboutus.

3. http://www. nationalshortstory week.org.uk/. 
4. http://www nationalshortstory week .org.uk/ noshortstorycuts.htm also an online petition at the moment, ${ }^{4}$ because Radio 4 have said they're going to cut their short stories slots to two from this November and then down to just one in Spring 2012. I was recently talking to publisher who was saying that e-books are a good way to publish short stories, because you can download them very cheaply, read one and then decide if you want to buy the book and that could potentially revolutionize things, especially for the cousin of the short story, the novella.

Q: Is that because a short story would be the right length to read on a Kindle during a commuting train journey?

A: I've been trying to think about this, because as a lot of people, including William Boyd have said, a short story is about so much more than shortness (Boyd 2006). But it's often writers themselves who say things like, 'I don't know why people don't read short stories, because they can read them on the train'- so even short story writers are appealing to the notion of shortness and therefore being read quickly. But I think that the true appeal of the short story has more to do with the intensity of the reading experience, rather than the speed of the reading experience. Short stories were more popular in the past, when Penguin used to produce volumes and volumes of short stories. So if it was all about our busy lives, and being strapped for time, you'd think the short story would have gone from strength to strength, but that doesn't seem to have happened - and perhaps that's because the short story is a slightly more difficult form.

Q: Or is it simply that publishers have stopped publishing short stories in favour of novels?

A: Perhaps, or maybe a mixture of both. I like reading both novels and short stories, but they are completely different reading experiences and we approach them in different ways.

Q: Lorrie Moore wrote that a short story is a love affair, a novel is a marriage; a short story is a photograph, a novel is a film. Do you think that's so?

A: There are all these analogies about the short story: that the novel's a marathon, whereas the short story's a sprint; or the novel's a mural, the short story is a miniature. I think they're indicating what it's possible to do with each form. The short story has always been in the forefront of experimentation in a way that the novel hasn't, and it seems to be because of its shortness that you can do a lot more with it. For example, a novel written in the second person could be really wearying, whereas Lorrie Moore, for example, has written a number of excellent short stories in the second person.

Q: I've noticed in your own stories that you often move from first to third person, and from the historic present to the past tense very fluidly in a single story.

A: I think that's really about the story dictating how it needs to be. Most people seem to have a natural mode of writing they feel comfortable in, and for short stories the most popular mode seems to be the limited third person narrative - certainly in the American short stories I read - and it's also a good way to portray certain inarticulate characters. In my collection, about half the stories are in the first person and half are in the third. I just wait and see what the first line of the story is. Lorrie Moore has got a good quote: she says that 
a short story is like a having a weekend with a lovely, mad stranger who then goes out of your life. My favourite quote is by Nadine Gordimer, that the art of the short story writer is like the flash of fireflies - now here, now there, now in the light, now in the darkness - and she says that this mimics our life; the quality of human relationships where people don't stay married to the same people, or live in the same place - the short story imitates the modern experience of fragmentation.

Q: An Italian short story writer, Paulo Bacigalupi, said that'Short fiction seems more targeted - hand grenades of ideas, if you will. When they work, they hit, they explode, and you never forget them'.

A: Yes. Even at the most basic level, short stories can be memorized in a way that your favourite novel can't - you can almost remember whole short stories word-for-word. The most basic short story was a fairy story, an oral tale which people would tell and re-tell in different ways, so I suppose short stories do have that kind of resonance in ways that a novel doesn't.

Q: Is that compression part of what makes a good short story? I think it was Poe who said that short stories should have a unity effect, and that everything else in the story should be determined by that.

A: Poe was one of the first writers to really theorize the short story, and it's funny that when I teach him now he seems so old fashioned and melodramatic and wordy, and yet he was so innovative in his time. Part of his project was to overthrow the influence of the big, stuffy 'baggy monster' novels which were coming from England - writers like Charles Dickens. In some ways Poe's theory still holds, even though it's prescriptive. He thought you should start out with the whole story already planned and predetermined - and all that was left to do was to write it out, almost like ticking off boxes. But his idea about the short story being single-minded, not taking on too much as Chekhov says, 'Every word counts', and Carver says, 'Take out every word that's superfluous' - one constant has been that idea of economy; the idea of every word contributing towards the desired effect. That's what Poe was saying really: get rid of digressions; get rid of things that don't move the story forward; get rid of things that don't add to the theme of the story - which still holds true. Muriel Spark has also said that the short story is like poetry. People often consider how the short story is different from the novel, but it might be more interesting to look at how the short story differs from poetry. Maybe it's more allied to poetry than the novel, especially with the phenomenon of 'flash fictions' - these tiny little stories of a hundred words, or even five words, which are massively popular on the internet. They're like Hemingway's shortest story: 'For sale: baby shoes, never worn.' Just six words - this idea of economy, of cutting back and letting words build associations and implications, and open up story worlds without saying too much.

Q: Still following this idea of 'seeding' - every word and phrase contributing to the core idea of the story - in your story, 'I'm happy, you're happy, we're all happy' (Paul 2005), there's a line 'It was the way his face changed all the time, I watched all its alterations.'That's almost the seed of the story, planted in that early phrase.

A: I don't know how conscious writers are of these things. When I edit, then I take away a lot of digressions that I like - for example, a neighbour comes in, 
and she's not really anything to do with the story and she's a bit distracting. But I don't know how aware of this seeding authors are. I certainly think that sometimes it can be an albatross round your neck to start thinking of those things. In a lot of American short stories you'll see the symbol coming - even if it's a really good symbol - for miles. So maybe it's better for writers not to think too much about that.

I suppose the trick to editing is to try to turn yourself into a reader of your own work, rather than its writer. For example, as soon as a character's mentioned by name you think they've got some significant part to play in the story and you should pay attention to them. So you set a little trap in your head, and if that comes to nothing you feel a bit cheated. In a novel that doesn't matter, because you don't expect to pay attention to every character. Faulkner has some interesting things to say about the short story - he was a practitioner of both - and he said that short stories were harder to write than novels. I don't think it's particularly useful to think about short stories, or novels, or poetry being harder or easier than each other to write, but he says that the real skill, the real artistry, is in the short story. One big difference, of course, is that if you're writing a novel you have to live with it for a long time - George Orwell says it's like a long illness: 'Writing a book is a horrible, exhausting struggle, like a long bout of some painful illness. One would never undertake such a thing if one were not driven on by some demon whom one can neither resist nor understand' (Orwell 1971). Personally, I've never been able to generate that kind of commitment to a novel - in the past I've started, and got to 30,000 words and then felt bored with it. I've never had the relationship with characters that novelists seem to have - like Tolstoy who was surprised to discover that Anna Karenina was going to kill herself, and Flaubert said 'Madame Bovary - that's me'. Some novelists speak of their characters as if they're intimate friends. I've never felt that when writing a novel, or writing a short story. Maybe you need to be intensely attuned to your characters in a novel, in a way that you don't in a short story.

Q: Graham Greene said that because of the length of time that it takes to write a novel, not only your characters develop but you do as well; so the person who finishes the novel is quite a different person to the one who began it.

A: There's also a pragmatic thing about novels, that novels are difficult if you edit a lot as you go. You can't easily hold a novel in your head; you need to forge ahead and get the shape of it down. Whereas with a short story, everyday when I'm working on it, I'll read the whole thing twice. With a novel you can't see the end of the tunnel a lot of the time. I find that dispiriting. It's an interesting idea about the development of the author, but sometimes people spend fifteen years on the same short story. Tobias Wolf ${ }^{5}$ attests to this fact when he says ' $I^{\prime}$ ve had some stories in drawers for fifteen years, and I've been tinkering with them on and off until they were published.'

Q: That does sounds like the sort of thing poets do ...

A: I remember there was a huge outcry in Scotland because someone got $£ 15,000$ of arts funding money to write poems, and people were saying 'You don't need time to write a poem. A poem only takes a few minutes to write.' 
Q: One thing that strikes me about your short stories is how skillfully you use reported speech. There's a passage in 'Here Is Tragedy' (Paul 2005), when Toby is breaking up with Edith - the key moment in the story - but you do it in reported speech.

A: That was my breakthrough moment as a writer, when I learnt how to use reported speech. And although I'd done an MA in Creative Writing, I think writers teach themselves to write. I used to look at Alice Munro stories and try and work out - before I did any standard, formal training in creative writing - how she did it: how she moved a scene on; how she speeded a scene up. And this is what I tell students, that this is what writers have done from time immemorial: they have taught themselves to write by studying and deconstructing how the authors before them have done things, technical things such as inscription of place, point of view and so on. Reported speech is a great tool for the short story writer, in terms of speed. What I try and do what you can do with reported speech - is a kind of distillation of speech, or an intensification of speech. And people can talk about more philosophical, religious things that would seem really quite pretentious or strained related in direct dialogue. Of course there are great short story writers whose characters speak with a Tennessee Williams-style eloquence, and that works as well, but that wasn't the way I wanted to do it. It's funny, because people have often said to me, 'The dialogue in your books is good,' and in fact when my stories were broadcast on the radio, the woman who contacted me said she wanted to use my stories because I was good at dialogue. But actually, there's hardly any dialogue in the stories, it's mostly reported speech. Frank McCourt, who wrote Angela's Ashes (1996), didn't use any dialogue, it's all reported speech, but people don't pick it up because when it works it's fast and it gives you an idea of how people talk, and it allows you to put a slant on how people talk.

Q:You took two degrees which included Creative Writing, an MLitt and a Ph.D. What do you think you learnt from those courses - about the writing process, or the profession of writing - which you wouldn't have found out for yourself?

A: When I took my Masters degree, they'd only been going a year or two, and it was much more un-formalized and un-academic: 'Come together all you who like writing.' It's much more regulated now, students have to write critical commentaries, but we never had to comment on or analyze or provide any kind of reflexive commentary on our own writing. It was more like a kind of jamboree, a get together. I got a lot out of it - I met friends who I could talk to about writing, people who cared about where you placed a comma and were willing to argue about it. I loved that, and I loved reading other people's work. It's endlessly interesting if you're also writing to see what other people are doing. I can't remember ever getting my work 'workshopped' by other students, but what I do remember is that we had individual tutors, and mine was Zoe Wicomb who was brilliant, and has helped me ever since. She's been absolutely central to everything I've done, and she would read my work and say, 'Good, carry on.' It was having another person to say, 'Yes,' - apart from my Mum. Having someone believing in me was a huge thing for me at that point, and being in an environment where people were talking about books, and reading and writing. The other thing about doing the course - and I feel ambivalent about this, even though I benefitted - was that in a way you were paying for connections, because publishers and agents came to give us talks. And a big part of me resists that kind of set-up, because if you're on the 
outside of it then you're really at a great disadvantage - if you're just writing things at home and sending pieces away. In my case, a publisher came to my University to give a talk, and offered to read our work afterwards. I gave her a few short stories. Then she asked to see the rest of them, and then a few weeks later I got an e-mail offering me a publishing deal. It very, very rarely happens like that. So the course gave me that.

Q: What do you think are the most valuable things that you are teaching your creative writing students?

A: I try to avoid doing things that I would have hated to have done when I was a student. For example, I would have died reading out work aloud. I don't like sitting in a workshop, writing something and then reading it out. For me, writing's something that you do by yourself, in private. Alice Munro calls it, 'wooing distant parts of myself.' What I think students can get out of creative writing is that they can become good readers, and good editors of their own work. So in my classes we read a lot of short stories, because a lot of students want to write short stories, but they don't read them. I've had undergraduate students who've come never having read one short story in their lives. Not because they don't like them, just they've never come across them. So we read a lot of stories, and we analyze them - we look at the use of the first person, we look at endings, we look at closure, we look at all the different technical elements that might go into a short story. I think that's really useful, because the short story has is own internal architecture. We look at the nuts and bolts of structure. You can make the students aware of technical issues to do with writing - so you can point out, for example, that someone's gone from past tense to present tense in one line. And although that doesn't make a great writer, it does make the students aware of the fundamentals. I hope the students learn how to be consistent, to watch out for clichés, how to edit their own work through a process of helping each other edit their work, reading each other's work.

Q: But aren't those more reading skills than writing skills?

A: I think reading skills are important, especially when writing short stories which are dependent on structure. You cannot teach people imagination. What you can teach people - going back to T. S. Eliot - is about the perspiration, the critical labour, that goes into writing. A lot of students arrive thinking that if you sit and try and write something for an hour and nothing happens, then there's no point continuing. You teach them about the hard work, the work ethic, the commitment and craftsmanship. Raymond Carver, for example, said that he never did less than ten drafts of a story. And I think that's helpful - it means they don't give up when something doesn't work straight away. What a lot of students like are prompts for their imagination, writing exercises. I think undergraduates come in and they don't perhaps have a 'voice' - I know it's a vexed term - and you can help them by encouraging them to read and write in different styles.

Q: How do you feel about BA writing courses - teaching students who, especially now, have spent their school lives being crammed for a succession of tests, with creative work being pushed more and more and more to the margins?

A: I think there are brilliant old writers and young and middle-aged writers - I hate the ageism you sometimes hear in the publishing world. We take it for granted that people study art or music, and writing has rules of perspective 
and shading just like painting. Artists are taught those things - and the history behind what they're doing and how it fits in. So why shouldn't writing students be taught that, too?

Q: Do you think there's a danger that the theory growing up around creative writing is damaging the practical teaching in the attempt to create an accepted academic discipline?

A: I think we're fortunate at Anglia Ruskin that the staff are very supportive of creative writing. At other universities - even those where creative writing is bringing in a lot of cash - the academic staff don't take creative writing very seriously. There's a famous anecdote that when Nabokov was appointed as a professor at Harvard, one of the English professors said, 'What next? An elephant teaching zoology?' I think the danger can be that students believe they have to write in a certain way, and that only certain things are allowed. Obviously no good art would ever be produced if everyone followed a set of rules and proscriptive instructions. Truman Capote said, 'If you're born knowing [the rules], fine. If not, learn them. Then rearrange the rules to suit yourself' (Hill 1957). It's getting the balance, so the students are aware of techniques like focalization and free indirect discourse and timing, and can be self aware about when and why they're breaking conventions. Alice Munro's story 'Material' (Munro 1997) is a very good commentary on writing and on the process of turning real life into writing. It starts with her going to a creative writing class where the tutor says, 'You've got too many people in your stories, and also not enough happens.' And of course, Alice Munro breaks all the rules, she has loads of people, she has digressions, sometimes it's hard to know what the story's about, often resolutions are deliberately thwarted, and denied to the reader.

Q: Do you think that the modular system, in which every assessment after the first year counts towards their final degree mark, inhibits students from experimenting - from breaking the rules?

A: I don't think that's the case, if for no other reason than we give students every encouragement to write out of class, and to show the work to us - their regular tutors - or to our two Royal Literary Society Fellows. And the issue is students not producing anything - some talk about writing a lot more than they do it: 'I've got twenty ideas for a short story, and I'm not sure which on I should do, so I'll just think about them. My first idea is ... and my second idea is ... and my third idea is...' In the end they never put pen to paper, and this isn't the students being lazy. It's what we all feel: it's fear that all our brilliant ideas, once we write them, will be terrible failures. If you care about it, it'll never be as perfect as it is in your head, you'll spoil it by writing it down. You have to urge the students to sit down and write anyway. As Flannery $\mathrm{O}^{\prime}$ Connor says, writing is an act of discovery, or as E. M. Forster said, 'How do I know what I think until I see what I say.' It's getting started that's hard, and getting finished which is even harder.

\section{REFERENCES}

Boyd, William (2006), 'A Short History of the Short Story', The Quarter, http://www.theshortstory.org.uk/downloads/boyd.pdf. Accessed 14 November 2011. 
Hill, Patti (1957), 'Interview with Truman Capote', Paris Review, no. 17, www. theparisreview.org/interviews/4867/the-art-of-fiction-no-17-truman-capote. Accessed 14 November 2011.

Lahirir, Jhumpa (1999), Interpreter of Maladies, Boston: Houghton Mifflin/ Harcourt.

Munro, Alice (1997), Selected Stories, London: Vintage.

Orwell, George (1971), 'Why I Write', The Collected Essays, Journalism and Letters of George Orwell, Vol 4, Boston: Houghton Miflin/Harcourt.

Paul, Colette (2005), Whoever You Choose To Love, London: Phoenix.

Wolff, Tobias (2004), 'The Art of Fiction No 183', Paris Review, no. 183, http:// www.theparisreview.org/interviews/5391/the-art-of-fiction-no-183-tobias-wolff. Accessed 14 November 2011. 